\title{
Personal Learning Environments and the Diversity of Digital Natives
}

\author{
Phillip L. Davidson \\ School of Advanced Studies, University of Phoenix, Phoenix, Arizona, USA \\ Email: phil.davidson@phoenix.edu
}

How to cite this paper: Davidson, P.L. (2017) Personal Learning Environments and the Diversity of Digital Natives. Open Access Library Journal, 4: e3608. https://doi.org/10.4236/oalib.1103608

Received: April 14, 2017

Accepted: May 13, 2017

Published: May 16, 2017

Copyright (c) 2017 by author and Open Access Library Inc.

This work is licensed under the Creative Commons Attribution International License (CC BY 4.0).

http://creativecommons.org/licenses/by/4.0/

\begin{abstract}
Personal learning environments (PLEs) are defined as an approach that integrates informal and formal teaching with tools and technologies which are part of web 2.0. Web 2.0 refers to the collection of applications common to internet users such as blogs, wikis, social media, and other forms of collaboration and instant communication. The force behind the momentum to make PLEs available to our students is a belief that students are younger and more technologically adept, sometimes termed "digital natives." The argument is that these digital natives, who were born into a total digital age, will learn better if they have the tools they commonly use, such as social networking and IM, to complete their school work. PLEs involve collaboration among peers through a variety of technologies. While much of the academic research seems to have accepted the premise that our younger students think and learn in a unique way, other research supports the idea that a total dedication to PLEs might be an error and might work against the ability of students to learn. These arguments, pro and con, are found within this paper as well as a brief discussion of the challenges the implementation of PLEs might have on a university's ability to support such a process. There are significant concerns about the readiness of faculty for the implementation of PLEs. There is concern, as well, regarding the ability of universities to pay the costs of modifying their online learning system infrastructure to support full access to web 2.0 within the university's current technology and security systems.
\end{abstract}

\section{Subject Areas}

Education

\section{Keywords}

Personal Learning Environments, Digital, Web 2.0

\section{Introduction}

Discussions of how we educate (e.g. pedagogy versus andragogy) and how we 
learn are engaging topics that have occupied the attention of authors and educators for at least a hundred years. A difficulty, however, may occur when the discussion gets involved with the technology of learning. The difficulty arises because there is a plethora of technologies and a wide variation in student skills and learning styles. The technologies now available for teaching, learning, and online collaboration are almost uncountable, and the number expands virtually every day. The value of these different technologies is in the diversity of the tools. The diversity of the technologies and tools allows for a wider incorporation of a diverse student body. Having access to a wide variety of communication, collaboration, and other classroom tools that fit the student's needs seems like the next logical step forward.

There is an assumption, as noted in the works of Allen and Seaman (2013) [1], that it is essential that institutions of higher learning incorporate all the web 2.0 tools in order for students to enhance their ability to collaborate, communicate, and learn. The ability of students to personalize and choose the tools they use to learn is strongly supported by many energetic academics. That powerful support threatens to preclude a serious discussion about some of the underlying assumptions involved with the use of PLEs in teaching, and the possible downside PLEs might have with learning or education itself.

The purpose of this paper is to examine some of the modern technologies being put in place within education, specifically the tools and technologies that describe "Personal Learning Environments" (PLEs) which involve the tools associated with web 2.0. The paper continues with an examination of the mindset that is actively pushing for the implementation of PLEs, based on the belief that our new learners have a different mental framework. Described as "digital natives" by Prensky, 2001 [2], the argument is being made that our students are fundamentally different from previous generations. This perceived fundamental difference is the impetus behind the increasing pressure to implement PLEs.

Within this paper, the discussion will deal only with the online learning. There is an important reason for this focus. Increasingly, students worldwide are making use of distance learning via the internet. A survey by the Babson Survey Group, Allen and Seaman, 2013 [1] indicated nearly seven million students in the United States (almost a third of the total student population) have taken at least one online class. Despite the ongoing debate about online versus traditional educational pathways, online education has grown four to five times faster than traditional educational pathways [1]. The growth of online education is largely attributed to the technology, such as the internet, which allows students who cannot afford to quit their jobs or travel to live on a campus, the ability to get a quality education. The effect of technology on education is clear and the fact that more students can avail themselves on learning opportunities must be considered a plus.

The challenge and the concern, however, is not the technologies, but the students. The problem is that so much attention has been given to the technologies, that the students have almost become secondary. In addition, the gross generali- 
zation about the student population seems to have been so widely accepted that very few discussions about the individual students are taking place. This reduction in diverse thinking about our learners runs counter to the purported purposes of PLEs, which is the ability to deal with tremendous diversity within our students' learning styles. These issues need to be examined more closely.

\section{Personal Learning Environments}

The definition of Personal Learning Environments is still evolving, but one definition offered by Dabbagh and Kitsantas, 2012 [3] was "a ... pedagogical approach for both integrating formal and informal learning using social media and supporting student self-regulated learning in higher education contexts" (p. 3). Personal learning environments frequently include discussions of Web 2.0, which is the integration of the various tools available on the internet (e.g. blogs, wikis, and social networking) towards a singular purpose [3]. Conradie, 2014 [4] argued that PLEs reflect a new paradigm that reflects a "more intrinsic approach to learning in the 21 [sic] century" (p. 254). Are PLEs a new paradigm or a more focused use of technologies?

Personal learning environments are a growing trend in online education with an emphasis on students being able to define their own learning environment. The focus is on self-directed learning, allowing students to take an assignment, and research it through both traditional and non-traditional means (internet, blogs, wikis, social-media, etc.). Students are also encouraged to collaborate with other students in completion of their assignments. This process of collaboration and use on non-traditional data for completion of assignments is one significant concern of faculty related to PLEs.

While there has been significant discussion in the research literature over the last ten years regarding PLEs, most of the discussion is still contradictory and theoretical. Researchers continue to argue about the definition [5] or the potential [6], yet there has been some impressive and interesting research. Jörg, Alexander, and Ulrike, 2014 [7] suggested ways to bring existing tools and services together for PLE creation, while Victoria, Jesús, \& Bárbara, 2014 [8] provided an exploratory study of two PLE configurations. The research has been interesting and promising. For those academics that see the ability of different tools possibly enhancing student learning, the idea is exciting. The concern is that, in our excitement for the latest technologies, we may be overlooking the teaching of essential knowledge skills that make PLEs potentially valuable. Even more potentially bothersome is the blanket assumption that all our students are "digital natives" and can benefit from this new "paradigm".

\section{Digital Natives}

Prensky 2001 [2] was the first to coin the term "digital natives." Prensky tried to make the case that the students of today are not just different, as all generations are always a little different from the previous generation. Prensky argued that the change in these younger students (born about 2000 and beyond) is so fun- 
damentally different from any changes in the past, that he borrowed a term from artificial intelligence (AI), referring to this change as a "singularity." A singularity from the perspective of AI refers to the future possibility of super computers that become self-aware. While that may not have been Prensky's meaning, he argues that, because of today's younger students having grown up in a total digital age, these students process information differently. Prensky goes as far as to suggest that these new students may even have evolved different brain structures. If this is an accurate representation, which has not been affirmed in research, then it could be seen how faculty, even computer literate faculty, whom Prensky defines as "digital immigrants," might be ineffective in teaching these new digital natives.

The idea of digital natives (AKA n-gen [for the internet generation]) or d-gen (or the digital generation), was not a new idea with Prensky. The millennials (AKA Gen-Y) who were born around 1985 and later, have been frequently described as students who "do not know a world without computers," (p. 98) [9]. The point, however, is not the names or the generations, but about the casting of an entire generation as a unified group of people. Agreed that those born after 1985 (definitions differ) may be unfamiliar with photographic film or rotary phones, the question is not about different experiences but about whether they learn differently. Because these generations have been immersed in a digital world, the media and a great deal of academic research has been devoted to painting these generations as completely different and unique [10] [11]. While it is interesting and useful to understand how one generation might differ from another, there is a real concern that, from the perspective of academics, we might treat these students so differently that we forget the real purpose of what we are trying to accomplish. There is also the question as to whether these younger generations are really all that different.

In an article published in the Educause library, 2009 [12] about PLEs, it is stated that PLEs "require students to engage in ongoing decision-making to maintain, organize, and grow their learning environments. The process of selfdirected learning requires a degree of self-awareness, and it must be given time to mature" (para. 5). The article continues, "Some students, however, may have never taken the time to think about their own metacognition or to reflect on how they learn best" (para. 5). The suggestion is that while PLEs offer a wide variety of interesting, visual, and digital tools that appear interesting to the d-gen students, the students may not be ready to mentally handle the responsibilities inherent with the PLE environment. Some students might resist this approach and do worse.

In a study by Vance, 2012 [13], a large group of university students $(\mathrm{N}=1847)$ was surveyed. The students indicated that they liked the online social interaction, which might be expected. However, the students also showed a preference for traditional instruction with online support. One telling statement from that study noted that, "While students acknowledge how Web 2.0 activities and technology can promote critical thinking and reflection, they had doubts about 
the quality of education related to those activities" (p. 490). At the same time, there are good studies by Gallego and Gamiz, 2014 [14] and del Barrio-García, Arquero, and Romero-Frías, 2015 [15] demonstrating the perceived usefulness of PLEs by students which have demonstrated positive learning and knowledge acquisition.

The goal is not to discourage universities from implementing Web 2.0 tools (those that are used in PLEs). The concern is that the rush to implement these new technologies may be made without further consideration of the impact on students. Students favor the use of the digital technologies that they use for recreation. If those technologies, such as texting and social networking, add to their ability to learn, then this is a positive step forward. However, PLEs are basically self-directed learning environments. As the Educause [12] article suggested, we cannot be certain that it is in the students' best interest to turn them loose without a better understanding of the proper pedagogy to help them utilize all the tools they have available. How to we assure ourselves that students have the skills to filter information as found on the internet? What are we leaving out of the process to help the students understand about learning?

One consideration that cannot be ignored is the teachers themselves, those that Prensky [2] would label as "Digital Immigrants." Faculty are typically older and are not part of those generations totally immersed in digital technologies. While many have implemented digital media and social networking in their classes, there may be a need to spend some significant time with faculty first. Shaikh and Khoja, 2014 [16] conducted a Delphi study on PLEs and teacher readiness to teach in those environments. The results indicated that while the teachers selected were positive about the idea, traditional pedagogical tools need to be updated and training is essential.

\section{The Dollars and Cents of PLEs}

Several financial aspects need to be considered in the discussion of personal learning environments. Most PLEs are designed to run within established Learning Management Systems (LMSs), which is a positive. However, there are the issues of communication between disparate systems and students using multiple personal devices that may or may not communicate effectively with the LMS. This area has not been studied in a substantive way.

Another area that has not been well studied is the disparities in access to the technologies available in PLEs. Most of the studies done to date are in developed countries. That should not stop the developed countries from implementing tools that enhance a student's ability to learn, but are those people born after 1985 in developing countries still classified as "digital natives?" Does this widen the digital divide that already exists?

One last economic issue is the competition for students. As the number of online programs and universities increase, the competition for students has also increased. As far back as 2005, Dronholz [17] noted that institutions of higher learning are finding it increasingly difficult to be profitable or meet their ex- 
penses, so the competition to enroll new students and to retain current students is significant. Personal Learning Environments are potentially a highly effective marketing tool in attracting the younger learners. There is a responsibility (hopefully) that institutions focusing on the implementation of PLEs are primarily focused on providing a quality education over a positive financial statement.

\section{Conclusion: The Intellectual Implications for Students}

Personal learning environments are exciting for those that enjoy technological innovation. In this short paper, PLEs have been briefly outlined. PLEs use Web 2.0 tools that allow students to seek answers and collaborate on their schoolwork using a wide variety of pathways include social networking, texting, or writing blogs. This idea of using any digital tool with which students feel comfortable is perceived positively by many "digital natives" and some faculty members. There are concerns, however, as to whether the focus on technology is negatively affecting actual learning. Many research studies have presented data that students perceived they learned better within PLEs, while other studies have provided data that many members of the d-gen prefer more traditional educational instruction. It is possible that the best solution is somewhere between, combining some of the newer digital technologies with more traditional teaching methods. However, this is not just a philosophical discussion as the specific direction taken by institutions of higher learning could have long term positive or negative effects on student learning and comprehension. The discussion is far from over, and concerns raised regarding the economics of implementing and supporting PLEs versus the potential upside marketing advantage needs to be considered.

\section{References}

[1] Allen, I.E. and Seaman, J. (2013) Changing Course: Ten Years of Tracking Online Education in the United States. http://www.onlinelearningsurvey.com/reports/changingcourse.pdf

[2] Prensky, M. (2001) Digital Natives, Digital Immigrants, Part 1. On the Horizon, 9, 1-6. https://doi.org/10.1108/10748120110424816

[3] Dabbagh, N. and Kitsantas, A. (2012) Personal Learning Environments, Social Media, and Self-Regulated Learning: A Natural Formula for Connecting Formal and Informal Learning. The Internet and Higher Education, 15, 3-8.

[4] Conradie, P.W. (2014) Supporting Self-Directed Learning by Connectivism and Personal Learning Environments. International Journal of Information and Education Technology, 4, 254-259. https://doi.org/10.7763/IJIET.2014.V4.408

[5] Kompen, R.T., Monguet, J.M. and Miguel, B. (2015) Constant Change: The EverEvolving Personal Learning Environment. Quarterly Review of Distance Education, 16, 119.

[6] Rahimi, E., van den Berg, J. and Veen, W. (2015) A Learning Model for Enhancing the Student's Control in Educational Process Using Web 2.0 Personal Learning Environments. British Journal of Educational Technology, 46, 780-792. https://doi.org/10.1111/bjet.12170

[7] Jörg, H., Alexander, K. and Ulrike, L. (2014) Moodle \& Co. on the Road to Personal Learning Environment. E-Learning and Education, 1. 
[8] Victoria, M.J., Jesús, S.I. and de Benito Crosetti, B. (2014) Research Results of Two Personal Learning Environments Experiments in a Higher Education Institution. Interactive Learning Environments, 22, 205-220. https://doi.org/10.1080/10494820.2013.788031

[9] Oomen-Early, J. and Early, A.E. (2012) Teaching in a Millennial World: Using New Media Tools to Enhance Health Promotion Pedagogy. Pedagogy in Health Education, 1, 98-107.

[10] DeVaney, S.A. (2015) Understanding the Millennial Generation. Journal of Financial Service Professionals, 69, 11-14.

[11] Smith, T.J. and Nichols, T. (2015) Understanding the Millennial Generation. The Journal of Business Diversity, 15, 39-47.

[12] Educause.edu (2009) 7 Things You Should Know about ... Personal Learning Environments. https://net.educause.edu/ir/library/pdf/eli7049.pdf

[13] Vance, L.K. (2012) Do Students Want Web 2.0? An Investigation into Student Instructional Preferences. Journal of Educational Computing Research, 47, 481-493. https://doi.org/10.2190/EC.47.4.g

[14] Gallego, M.J. and Gamiz, V.M. (2014) Personal Learning Environments (PLE) in the Academic Achievement of University Students. Australian Educational Computing, 29, 1-14.

[15] del Barrio-García, S., Arquero, J.L. and Romero-Frías, E. (2015) Personal Learning Environments Acceptance Model: The Role of Need for Cognition, e-Learning Satisfaction and Students' Perceptions. Educational Technology \& Society, 18, 129.

[16] Shaikh, Z.A. and Khoja, S.A. (2014) Personal Learning Environments and University Teacher Roles Explored Using Delphi. Australasian Journal of Educational Technology, 30, 202-226. https://doi.org/10.14742/ajet.324

[17] Dronholz, J. (2005) Higher Education: More Students, Higher Prices, Tougher Competition. The Wall Street Journal, R.4.

Submit or recommend next manuscript to OALib Journal and we will provide best service for you:

- Publication frequency: Monthly

- 9 subject areas of science, technology and medicine

- Fair and rigorous peer-review system

- Fast publication process

- Article promotion in various social networking sites (LinkedIn, Facebook, Twitter, etc.)

- Maximum dissemination of your research work

Submit Your Paper Online: Click Here to Submit

Or Contact service@oalib.com 